\title{
Textual and Rhetoric Analysis of News Headlines of Urdu and English Newspapers
}

\author{
Muhammad Arfan Lodhi ${ }^{1}$, Sumera Mukhtar ${ }^{2}$, Shahnaz Akhtar ${ }^{2}$, Kishwer Nafees ${ }^{3}$, Naheed Akhtar $^{4}$ \& Hafiz \\ Muhammad Sajid ${ }^{5}$ \\ ${ }^{1}$ Lecturer, Higher Education Department Collegiate Wing, Punjab, Pakistan \\ ${ }^{2}$ Lecturer, The University of Lahore Pakpattan Campus, Pakistan \\ ${ }^{3}$ Headmistress GGHS 283 EB, Burewala, Pakistan \\ ${ }^{4}$ Headmistress GGHS 63 EB, Pakpattan, Pakistan \\ ${ }^{5}$ Principal GHS FS Minchanabad, Pakistan \\ Correspondence: Muhammad Arfan Lodhi, Lecturer, Higher Education Department Collegiate Wing, Punjab \\ Pakistan. E-mail: samaritan_as@hotmail.com
}

Received: August 13, 2018 Accepted: December 2, 2018 Online Published: December 29, 2018

doi:10.5539/ijel.v9n1p324 URL: https://doi.org/10.5539/ijel.v9n1p324

\begin{abstract}
Media discourse is powerful tool of making or breaking the image of any person, event or even idea among masses. Media houses deliberately employ different linguistic, rhetoric and emotional techniques to propagate their ideas in this age of information as well as misinformation. This study attempts to scrutinize print media news headlines by relating how different newspapers show similar event in different ways. The study was exploratory in nature and qualitative methodology was used to determine sample, gather data and further analyze it with narrative interpretations. 06 Pakistani newspapers were selected with equal number of English and Urdu newspapers to determine the sample of the study in form of news headlines. Data was analyzed through the technique of content analysis at textual, discursive and social practice level. Findings divulge that there is significant difference of linguistic and discursive markers among headlines of different newspapers. Certain level of ideology, power and hegemony factors were also found in the news of different newspapers. The apparent reason for using different linguistic and contextual techniques is to create entertainment, sympathy, embarrassment or amusement in the minds of the readers.
\end{abstract}

Keywords: media discourse, newspaper headlines, textual analysis, discursive practices, power and hegemony

\section{Introduction}

Today people are living in the advanced world of communication. In this age of fast communication, media plays its role as a source of providing information and framing ideology. Media is a vast field that deals with communication. TV, radio or newspaper are various modes of communication. Every mode of communication is considered partial. When it portrays any issue, it keeps in mind its own perspectives and ideologies. Media gives information to public but at the same time it affects the mental stance and cognitive posture of the public. Media is power as it has penetrated in our lives like oxygen in our body. Things are seen by people with media's eye and interpreted accordingly. Our views about world around us are shaped by media. In today's world it is possible to live without culture but it is not possible to live without media. People depend on media for getting the latest news about their surroundings. Media is fulfilling their informational needs.

In Pakistan, information usage and consumption have been changed due to media developments in recent years. Thousands of events happen simultaneously. These events are being reported to audience in time by media. However, media people determine the priority of news items. It's through media that people get information about local and global events. People depend on media for getting information and the latest news. The role of media becomes crucial to prioritize and rearrange agenda of news. In this way media influences people. People base their perceptions about the world on second hand reality which they receive from media. In this way they may create distortion in information. So, in recent decades the role of media is enhanced.

In the past, print media in Pakistan had the status of being objective and mature source of information but 
recently popular and crispy style is being adopted to enhance ratings in the race of profit. According to McQuail (1994) "since the early 1970's, the belief that mass communication is a powerful force has gained strength, in part from studies that document a correspondence between the amounts of media attention an issue receives and the amount of public concern about the problem".

Newspapers not only give information but also make people's opinion. They function as a special tool of language to propagate agendas of different social, political and economic pillars of power. When a person reads a newspaper with critical point of view, he is surprised to find out excessive use of some specific methods. He becomes aware of the situation when he comes to know about these particular techniques being employed by the newspapers. He uses his evaluative abilities to discover the hidden motives of words. He is able to find out the agendas being accomplished through particular manipulation of language and how ideologies are being constituted through different techniques used by the newspapers. One example of manipulation of language is through news headlines.

News headlines are the greatest way of describing different issues prevailing in the society at a particular time. Headlines provide information to all particularly to busy people who cannot find spare time to read the whole stories. With every passing day, the analysis of newspaper headlines is getting more and more significance. It is due to the increasing influence of newspapers in the world. Headlines are considered the gist or the most important part of newspapers. They can be skimmed by a reader and help the reader to get an outline of the important news of the day (Ghannam, 2011).

\subsection{Statement of the Problem}

Newspapers report the same event in different ways by manipulating headlines. The headlines used in newspapers increase or decrease news worthiness of any incident or event. The current study is an attempt to find out the textual and contextual differences by using different aspects of Critical Discourse Analysis. It concentrates on the issue how different newspapers use headlines deliberately to manipulate the events. Different media houses portray similar type of events in different ways. The apparent reason for using different linguistic and contextual techniques is to create entertainment, sympathy, embarrassment or amusement in the minds of the readers. Moreover, Urdu and English newspapers use a variety of linguistic and rhetorical techniques in order to draw the readers' attention. The most common problem is to understand the nature of news and news worthiness through discussing their different linguistic, discursive and social features.

\subsection{Objectives of the Study}

1) To find out significance of headlines in perspective of discourse and society.

2) To investigate the role of headlines in representations of same event in different ways.

3) To find out the impact of headlines in construction and propagation of ideologies.

4) To find out linguistic similarities / differences in the headlines of various newspapers.

\subsection{Research Questions}

1) What is the significance of headlines in perspective of discourse and society?

2) What is the role of headlines in representation of same event in different ways?

3) What is the impact of headlines in construction and propagation of ideologies?

4) How similar / different linguistic features of headlines effect the social features of discourse within the society?

\subsection{Significance of the Study}

The study is very significant to highlight the textual and linguistic interpretations of the language used in newspapers. Media and power of media has become one of the positive as well as the negative aspect to bring reforms and amelioration in the society. The study is an attempt to highlight the importance of the language used in news headlines. It is also important to open new ways of reflection and discussion in the field of media, critical discourse and linguistics. It has highlighted various aspects of news analysis with gravity and brevity based issues of attracting consumers' attention towards any sequence of event and incident. The study is also significant in finding out how an incident can become hazardous and pains giving accident just due to the deliberate art of playing with the words and exploiting language and linguistic devices. 


\section{Review of the Related Literature}

\subsection{Discourse Analysis}

Discourse is a vast term having a number of subfields and disciplines. It is derived from Latin word "discursus" meaning "conversation or stretch of talk." There are many forms of discourse like speech, lecture, everyday communication, formal discourse, addresses, religious or political talk. Mainly discourses are of two types: spoken and written. According to Van Dijk we can simply understand the term Discourse as text and talk. It is a form of language that is used in both spoken and written language such as daily conversations, newspapers, texts etc. In the light of above mentioned definition, it can be noticed that the term Discourse contains a wide range of disciplines.

According to the definition of discourse given by Nawaz et al. (2010), there are three basic notions in any discourse. First, it is a unified, meaningful and purposive stretch of written and spoken discourse. Second it refers to language in action and third it is language of particular language variety. Celce-Murcia and Olshtain as cited in Nawaz et al. (2010) define discourse as:

A piece of discourse is an instance of spoken or written language that has describable internal relations of form and meaning (e-g words, structures, cohesion that relate coherently to an external communicative function of purpose and a given audience/interlocutor. The external function or purpose can only be properly determined, if one takes into account the context and participants (all the relevant situational, social and cultural factors) in which the piece of discourse occurs.

Richardson (2007) states that Discourse Analysis is extremely diverse field in nature methodologically, theoretically and analytically. Schffirin (1994) as cited in Richardson (2007) has argued that there are two general approaches to define discourse. First approach is called the formalist or structuralism definition to discourse. In this approach the focus is on the unit of language above the sentence. As this definition focuses on form of language so it is known as formalist approach. Second approach is known as functionalist definition to discourse. Here in this approach the focus is on specific function that is the language in use. There are different approaches of discourse analysis. The focus of some approaches is on social mechanism of language and their concern is with complex structures. The other approaches are concerned with analysis of people's conversations.

\subsubsection{Critical Discourse Analysis Framework}

CDA is distinguished from the frameworks of other discourse analysis by its feature of integration of ethical issues that are dealt in it. It can be said in other words that in CDA analysis is not done for the sake of analysis. The goal of such analysis could be to show how in certain patterns textual features are used or demonstrate genre or stylistic features. Not only textual analysis is included in CDA but also social, cognitive and historical contexts are included in its analysis as the creation of text is surrounded by all these features. A more comprehensive understanding of discourse is offered by such an analysis when all these elements are combined. Discourse is situated in both its social and cultural contexts and finally subtle ideologies are explained which are hidden in and between lines. The concern of CDA is to provide methods and tools so that the relations between discourse, society and culture can be studied empirically. Its principal objective is to reveal minute details of that discourse-society relation.

\subsection{Language of Newspaper Headlines}

According to Reah (1998, p 13), a headline is "a unique type of text that consists of a range of functions that specifically dictate its shape, content, and structure; and it operates within a range of restrictions that limit the freedom of the writer". The holder is defined in the compact edition of the Oxford English Dictionary as "[a] line at the top of a page in the page title in operation, etc., are given a title or caption with a book, newspaper, etc. The main title of newspaper is usually on the first page of a magazine or newspaper usually printed in bold headlines, and they summarize the main points of the story. In general, the entire news story is told by the editor or owner of newspaper. In other words, the titles are always placed above news story in larger font. In most cases, editors have vital information about the following story, which means that their role is to provide summaries. People are attracted to buy newspapers because editors work to create attraction in them. Media houses often try to transmit the ideology and belief system prevailing social structures through the rhetorical language used in newspaper headlines.

According to Van Dijk (1995), definitive characteristic of news headlines is to consider the information of the most important and obvious journalistic discourse shown by title and abstract on the subject or story consists. According to Ungerer (2000), a title "describes the essence of a complicated story in a nutshell. It is reported quickly and accurately and arouses the curiosity of the reader". Similarly, according Taiwo (2007: 324), 
publishers use strategic titles, choosing an emotional vocabulary and rhetorical resources and writing so that the impact can be made on the readers. Therefore, the titles show that news organizations consider the most important information people should know. The construction of the "reality" may be limited or at least enabled in the journalistic discourse by media companies in some way.

\subsubsection{Significance of Newspaper Headlines}

Generally, it is supposed that a meaningful message to readers is conveyed by the news headlines. According to Develotte et al. (2001) social, national and cultural representations are revealed by headlines that are being spread in a society at a specific time. Headlines have a wider readership as the people who buy newspapers at first look upon the headlines only.

In a newspaper, the position of article is based on the importance of the event and hierarchy of importance is also reflected by its structure: the headline is considered to be the most important part or gist of newspaper. Headlines can be skimmed by the readers. They are able to get a sketch of the news of the day and some idea of its relative impact and importance (Reah, 1998, p. 14). Reah (1998) focuses on the words used in headlines and their meaning; intertextuality is important considering that any culture will have a range of familiar phrases and sayings. He further studies the phonology, as a "special way of making a headline memorable is to use the reader's awareness of sound" (ibid). Lexical words are more useful in headlines than grammatical words which may cause ambiguity in some cases. Headlines also have a visual function. A headline can sometimes occupy more space than the article itself, such as when the printing is larger and bold. (Ghannam, 2011)

In newspaper headlines, the same event can be represented in different ways. Ideological distinctions are carried in these differences of representations. It is important to provide the readers the cues to interpret events. In this respect, choice of words is important. Lexical items in the headlines carry expressive value which implies the writers' evaluation criteria. Consequently, the selection of word meanings can be regarded as reflections of ideologies. According to Mardh, (1980) headline must be short enough that it could be read quickly but it should also be long enough so that it can present facts comprehensively. According to Mardh (1980), the average length of newspaper headline is about seven words.

\subsection{Morphological and Grammatical Features of News Headlines}

Newspaper headlines as a genre have been established by various studies and their characterizing features have been pointed out by researchers. "Distinctive telegraphic syntax" of English newspaper headlines have been analysed by Bell (1991). He has found that simpler and colloquial forms of expression are used mostly and the use of loaded expression with sarcasm and cynicism are also noticed by him. A study has been carried out by Khodabandeh (2007) in which English and Persian newspaper headlines have been compared by him. He has exposed that there is similarity in the use of dynamic verbs, active voice, short words, declarative sentences, finite clauses, and simple sentences and difference is observed in using tense forms, headline types, modification, and omission of words.

The subject of exhaustive research has been the analysis of linguistic features "which work subliminally in the newspapers' ideological practice of representation". The attention of linguists has been drawn by newspaper headlines as social or national representations. "National representations" as defined by Develotte and Rechniewski (2001, p. 6) "the knowledge systems that encapsulate knowledge about other nations and nationalities, the term being applicable to representations of one's own nation, people and country, and to representations of other nations". The vocabulary and rhetorical devices which were employed in 300 Nigerian newspaper headlines have been studied by Taiwo (2007). His purpose was to identify the ideologies that lie behind their constructions so he employed Critical Discourse Analysis.

Grammatical features and structures that were employed in British newspaper headlines were studied by Praskova (2009). His aim was to identify if there is difference in the structure of headlines from the stylistically unmarked common core. He randomly selected two hindered newspaper headlines from six different British newspapers. He compared the language of headlines with the grammatical rules of the common core. Significant differences in grammatical structures of broadsheet and tabloid newspapers were investigated. The result indicated that there is no significant difference between the language of headlines and common core structures despite the fact that a few features such as abbreviated structures and the frequent use of verb forms were observed more in the newspaper headlines|. He concluded that there might be a core grammar of British newspaper headlines which would be used almost equally by both types of newspapers. 


\section{Research Methodology}

\subsection{Research Design}

The study adopted exploratory design. In such research designs, reality is considered as multifaceted and no single truth can be accepted as level of measurement. In contrast to analytical or experimental frameworks, in exploratory research design, truth is multi layered and multi-dimensional. Furthermore, qualitative method was used to collect and analyze the data in the present study. The population of this study was newspaper headlines of Pakistani Newspapers. Out of the target population, 06 newspapers were selected to become the accessible population of the study. The newspapers selected under population were both English and Urdu newspapers. The data was collected from the newspapers published from January 2016 to August 2016.

\subsection{Sampling}

The sampling of study was consisted of headlines published in Urdu and English newspapers in year 2016 (From January 2016 to August 2016). The newspapers have been selected through convenient sampling techniques whereas news headlines were selected from different genres like political news, war news, business news, fashion news, sports news and crime news. The sample has been drawn in the form of newspaper headlines through purposive sampling techniques which is famous method of non-probability sampling criteria.

\subsection{Data Analysis}

The data obtained in form of news headlines was analyzed through applying the technique of content analysis. The objective, systematic and quantitative description of manifest content is done through content analysis. The purposes, motives and other characteristics of the communicators are revealed by doing content analysis. It helps in identifying the impact of content on the act, attitude or the intention of listeners and readers. While doing content analysis, two aspects of texts are considered important: the first is structuring of proposition and the second is combination and sequencing of propositions. The first is concerned with representing individuals and clauses analysis which represents action, processes and events. The second is concerned with organizing single clauses into structured whole. So, linguistic analysis of news-texts moves from smaller scale to large scale. On the other hand, small scale analysis or micro analysis involves analysis of words and sentences whereas large scale or macro analysis involves organization of meaning across a text as a whole.

The analysis of newspaper text has been done by adopting Fairclough \& Wodak model (1997) and Van Dijk model (1995). The framework of analysis adopted for analyzing newspaper headlines is shown as under:

Table 1. Framework of analysis

\begin{tabular}{lll}
\hline Textual Analysis & Discursive Practices & Social Practices \\
\hline Context & Semantic propositions & Social Relations \\
Purpose & Participants' description & Power \\
Types of Sentence & Choice of words & Ideology \\
Tone & Text Narrative & Hegemony \\
Atmosphere & Language Style & Micro Analysis \\
Evidence & Rhetoric devices & Topicalization \\
\hline
\end{tabular}

\subsection{Research Procedure}

At first stage data was collected from 06 national newspapers including 3 English newspaper and 3 Urdu newspapers. The data was collected within the time period of January 2016 to August 2016. The dates of these newspapers were selected randomly. However, the headlines were selected through purposive sampling techniques. Data once gathered was then codified into different sub-categories. After the process of codification data was analyzed based upon Fairclough model of CDA and Van Dijk model of CDA. The reason of selecting these models was apparent as both these models are considered best to analyze media text. (Keller, 2008; Lagerwerf, 2002). Data was analyzed and interpreted qualitatively.

\section{Data Analysis}

According to Fairclough model, media discourse can be analyzed and interpreted at textual, discursive and social elements. All these three levels have been evaluated, discussed and interpreted in perspectives of different news headlines published in English and Urdu newspapers. 


\subsection{Textual analysis of News Headlines}

Following is given the textual analysis of the news, their interpretation and how similar event has been represented in differently in different newspapers.

HEADLINE \# 1: THE DAWN NEWS, JULY 14, 2016, "US COMMANDER CONFIRMS DEATH OF APS MASSACRE MASTERMIND KILLED."

CONTEXT: Khalid Khurasani killed in drone attack news confirmed by US Commander

PURPOSE: To break news of Khalid Khurasani death

TYPE OF SENTENCE: Declarative

TONE: Matter of fact, somber

CHOICE OF WORDS: Persuasive, convincing and affirming

EVIDENCE: Affirmed by US commander

ATMOSPHERE: Fast-paced and formal

LANGUAGE STYLE: Immediately draws the reader's attention

HEADLINE \# 2: THE DAWN NEWS, 14 JULY, 2016, "SIX AL QAEDA MEN KILLED IN OKARA VILLAGE: SAYS POLICE"

CONTEXT: In wake of police operation killing six terrorists

POINT OF VIEW: Third person omniscient

STYLE: Convincing and persuasive

EVIDENCE: Providing statistical detail: 6 terrorists killed

TYPE OF SENTENCE: Declarative

SPEECH: Direct

CHOICE OF WORDS: Persuasive and convincing

TONE: Matter of fact, Serious

HEADLINE \#3: THE DAWN NEWSPAPER 14 JULY,2016, “ HELD KASHMIR CONTINUES TO SIMMER AS STRIKE EXTENDED".

CONTEXT: In wake of Burhan wani death tension continues to mount up

LANGUAGE: Emotive language

APPEAL TO: Fear and safety measures

LITERARY TECHNIQUE: Sensationalism

EVIDENCE: Hypothetical evidence

ATMOSPHERE: Gloomy

WORD CHOICE: Lexis "Simmer" intensifies emotions and underlying plight of Kashmiris

TONE: Solemn

HEADLINE \#4 THE JANG NEWSPAPER 15 JULY, 2016, "BHARTI FOJ NY ZULUM KA BAZAR GARAM KR RKHA HAI, KASHMIRYON KI AWAZ KO DABAYA NH JA SKTA: MALIHA LODHI"

CONTEXT: In wake of Burhan Wani death and following riots erupt

TONE: Assertive

PURPOSE: Evokes sympathy and showing determination

FIGURATIVE LANGUAGE: Exaggeration and elaboration

POINT OF VIEW: Third person omniscient

LITERARY TECHNIQUE: Sensationalism 
LANGUAGE: Emotive

VOCABULARY: "zulum ka bazar garam" renders emotive coloring and intensifies the situation

ATMOSPHERE: Gloomy and somber

HEADLINE \# 5: THE NATION NEWSPAPER 15 JULY, 2016, "CHINA VOWS TO DECISIVE RESPONSE TO SEA PROVOCATIONS".

CONTEXT: Hanoi protests Beijing activities in South Asia Sea

POINT OF VIEW: Omniscient

ATMOSPHERE: Serious

PURPOSE: Exhibiting determination

APPEALS TO: Safety

PURPOSE: Informing about havoc that place in South Asia Sea

WORD CHOICE: "Promise" and "protest" shows their determination to carry out their mission

HEADLINE \# 6: THE JANG NEWSPAPER 15 JULY, 2016, “ BHARTI JABER K KILAAF MAQBOZA KASMIR OR PAKISTAN MA AJ YOM E MUZAMMAT MANAYA JAYE GAA”

CONTEXT: Burhan Wani's murder and follow up events in Kashmir

TONE: Authoritative and exhibiting determination

STYLISTIC DEVICE: Elaboration

PURPOSE: Resolution and calls for action to be united against Indians atrocities

POINT OF VIEW: Omniscient

SPEECH: Direct

SENTENCE: Declarative

HEADLINE \# 7: THE NATION NEWSPAPER 16 JULY, 2016, "PAKISTAN TO BOOST SUPPORT TO KASHMIRIS , TUESDAY TO BE BLACK DAY"

CONTEXT: Ongoing Indian atrocities in Kashmir, rallies held across AJK to slam Indian massacre

SENTENCE: Future indefinite, declarative

TONE: Passionate, Solemn and breaking news in determined manner

AUDIENCE: Means for all and sundry

PURPOSE: Calls or solidarity and integrity

LANGUAGE: Emotive language

APPEALS TO: Safety and patriotism

IMPACT: Evokes sympathy

CONTENTION: Humanitarianism

HEADLINE \# 8: JANG NEWSPAPER 16 JULY, 2016, "FRANCE MEIN PHIR DAHSHATGARDI, TRUCK HAMALAY MA HALAKATAIN 84 HO GAI, 50 SY ZAID KI HALAT NAZUK, MULK BHAR MAI SOUG"

CONTEXT: This tragedy happened when people were celebrating their national day

LITERARY TECHNIQUE: Sensationalism

TONE: Deplorable and sad

VOCABULARY: "Dahshatgardi", "halaktain","soug”, and "hamla" intensifies the situation and renders pathetic coloring to description 
CONTENTION: To inform about tragic incident took place in France

FACTS AND FIGURES: 84 killed and more than 50 are injured

EVIDENCE: Facts and statistics

APPEALS TO: Safety

IMPACT: Creates fright in mind and calls for safety measures

SENTENCE: Declarative

POINT OF VIEW: Omniscient

\section{HEADLINE \# 9: THE EXPRESS NEWS 17 JULY, 2016, "TURK AWAAM NY BAGHAAWAT KUCHIL K JAMHOORIYAT BACHAA LI"}

CONTEXT: Masses power helps Erdogan foils military coup

POINT OF VIEW: Omniscient

TONE: Assertive, enthusiastic or strong

IMPACT: Creates sense of democracy, solidarity and patriotism

CONTENTION: To instill sense of nationalism among people

SENTENCE: Declarative

VOCABULARY: "Bagawaat", "jamhooriyat bachaa li", "kuchal di", Presents accurate picture of army and civilians' struggle and brings this picture before readers' eyes

PURPOSE: To break news about the struggle of Turkish people

LITERARY TECHNIQUE: Sensationalism

APPEALS TO: Patriotism or nationalism

\section{HEADLINE \# 10: THE DAWN NEWS 17 JULY, 2016, “TURKISH GOVERNMENT ROUNDS UP 6,000 AFTER FAILED COUP"}

CONTEXT: Turkey widens crackdown on military judiciary

TONE: Moderate and diplomatic

SENTENCE: Declarative

FACTS AND FIGURES: Rounds up 6,000

POINT OF VIEW: Omniscient

LANGUAGE: Emotive language

EVIDENCE: Facts and statistics

LITERARY TECHNIQUE: Sensationalism

APPEALS TO: Patriotism

\subsection{Analysis of News headlines at Discursive level}

Fairclough highlights three level of analysis of media discourse. Textual interpretation of the news is first level, discussing their discursive features is second whereas social practices is the third level of the model. After lexical analysis, news was analyzed on discursive patterns. Discursive analysis of the selected newspaper headlines is given as under:

1) Semantic and Macro Proposition

2) Local Level: Participants description and lexicalization

3) Global Level: Super Structure of the sentence

Every news headline has been discussed at three different levels. At first, it was discussed at semantic level to understand how and in what manners the news has been conveyed. This level gives contextual information about 
the news as well the relationship of past occurrences and forecasted future events. Secondly, participants and agents of the news have discussed with special reference of hybridized lexical features present in Urdu as well as English news. At the third level, overall structure of the news has discussed to explore what the news actually portrays at surface level.

Table 2(a). News description of headline 1

\begin{tabular}{llllll}
\hline No. & Dawn Newspaper & The Nation Newspaper & Jang Newspaper & Express Newspaper & Khabrain Newspaper \\
\hline 1. & US commander & USA affirmed killing of & Amrica ne APS hamlay & APS hamlay ka mastermind & Drone hamlay mei maara \\
& confirms APS & APS mastermind in & k mastermind Umar & Khalid khurasani maara gaya: & jane wala mastermind \\
& massacre & operation. & Naray ki halakat ki & Ittehadi commander ki tasdeeq: & Khalid khurasani nikla: \\
& mastermind killed. & & tasdeeq krdi & General Raheel ko phone & Pak Fojj ki tasdeeq \\
\hline
\end{tabular}

Table 2(b). Interpretation of news headline

\begin{tabular}{ll}
\hline The Semantic Macro-proposition & $\begin{array}{l}\text { These are different headlines from different news papers. At the surface level they give } \\
\text { information about the death of mastermind Khalid khurasani. These headlines are } \\
\text { confirmative. These headlines also remind us of past event of 16 December 2014. It was a } \\
\text { terrorism incident one cannot forget in which innocent children were killed. The language used } \\
\text { in Urdu newspapers is comparatively more informative and rhetorically more intense as } \\
\text { compared to language used in English newspapers. }\end{array}$ \\
\hline $\begin{array}{l}\text { The news headlines tell about the major world power USA, General Raheel shareef and Khalid } \\
\text { khurasani. The words like "mara gaya" "killed" "marra jany wala" "halakat" a differentiating } \\
\text { attitude towards a group of people is created, as killed has a stronger connotation than died. A } \\
\text { Description and Lexicalization }\end{array}$ & $\begin{array}{l}\text { typical kind of language hybridization is also used in Urdu newspaper to intensify the gravity } \\
\text { of the news and its importance in local and international settings. }\end{array}$ \\
\hline The Global Super structure & These headlines simply summarize good news of the major terrorist's death. \\
\hline
\end{tabular}

Table 3(a). News description of headline 2

\begin{tabular}{llllll}
\hline No. & Dawn Newspaper & The Nation Newspaper & Jang Newspaper & Express Newspaper & Khabrain Newspaper \\
\hline 2. & Six Al Qaeda men & Six Afghan Taliban & Okara mei police aur & Okara hassaas idaron aur & Okara: Police aur \\
& killed in Okara & killed in Okara operation & hassaas idaron ki \\
village: Police & & karwai 6 dehshatgard & $\begin{array}{l}\text { police ka mushtarka operation 6 } \\
\text { dehshatgard halaak }\end{array}$ & $\begin{array}{l}\text { hassaas idaron ka } \\
\text { operation 6 } \\
\text { dehshatgard halaak }\end{array}$ \\
\hline
\end{tabular}

Table 3(b). Interpretation of news headline

\begin{tabular}{ll}
\hline The Semantic Macro proposition & $\begin{array}{l}\text { The news headlines describe police operation resulting in the death of } 6 \text { terrorists. The headlines } \\
\text { explicitly present the whole scene of fighting. In these headlines, words invite the readers to read } \\
\text { the full report to fully comprehend and feel proud on police officers who killed them bravely. } \\
\text { However, The usage of different words for terrorists can be found in English newspapers where } \\
\text { Dawn newspaper relates them to Al Qaeda and Nation newspaper linked them to Afghan Taliban. }\end{array}$ \\
\hline $\begin{array}{l}\text { The main participants are the Afghan Taliban and police in the city Okara. The words "hassasi } \\
\text { adaray" dehshatgard" usually create fears in the hearts of common masses. They create terror and } \\
\text { fear in the society. These words are very sensational. }\end{array}$ \\
\hline The Global Super structure & $\begin{array}{l}\text { This news headlines simply but effectively summarizes the whole incident. It ignores the } \\
\text { background of the news but message is delivered more comprehensively in Urdu newspapers. }\end{array}$ \\
\hline
\end{tabular}

Table 4(a). News description of headline 3

\begin{tabular}{llllll}
\hline No. & Dawn Newspaper & The Nation Newspaper & Jang Newspaper & Express Newspaper & Khabrain Newspaper \\
\hline 3. & Held Kashmir & Kashmiris express & Maqbooza Kashmir mei & Maqboza Kashmir curfew & Maqbooza Kashmir \\
& continues to simmer & solidarity with IHK & mukammal hadtaal Ali & jaari, hallat badd'stoor & mei tashadud par \\
& as strike extended. & people. & Geelani aur Meerwaiz & kasheeda, & tashveesh, pur aman \\
& & & giraftaar & yaum-e-shauhda manaya & hall nikala jae: Amrica \\
& & & & gaya & \\
\hline
\end{tabular}


Table 4(b). Interpretation of news headline

\begin{tabular}{ll}
\hline The Semantic Macro & A news headline is generally an encapsulation of the full news report theme. These headlines show the same. \\
proposition & $\begin{array}{l}\text { Urdu headlines are straight forward summary of news ever written in format "who-what-where-when". Kashmir } \\
\text { issue has not been resolved, strikes, people died, police physical remands on prisoners. Language used in } \\
\text { English headlines is devoid of solid emotions. }\end{array}$ \\
\hline $\begin{array}{l}\text { Participants Description and } \\
\text { Lexicalization }\end{array}$ & $\begin{array}{l}\text { Headlines focus on Kashmir issue. People are suffering. It portrays that a pitiable situation and circumstances } \\
\text { are unbearable. "hallat badastoor" "tashveesh nak" create great impact on readers. }\end{array}$ \\
\hline The Global Super structure & $\begin{array}{l}\text { The global structure of these news reports explicitly summarizes the horrific incidents of Kashmir but in very } \\
\text { different ways. }\end{array}$ \\
\hline
\end{tabular}

Table 5(a). News description of headline 4

\begin{tabular}{llllll}
\hline No. & Dawn Newspaper & The Nation Newspaper & Jang Newspaper & Express Newspaper & Khabrain Newspaper \\
\hline 4. & India indulging in & India threatens more & Bharti foj ne zulm ka bazar & Aqwam-e-Mutehida & Maqbooza Kashmir mei \\
& state terrorism in & tough action in Held & garam kr rakha hai, & mein Pakistani ehtjaj & Barbarriat, Mamla \\
& held Kashmir, says & Kashmir & kashmirion ki awaz ko dabaya & par Bharat ka shadeed & Aqwam-e-Mutehida mei \\
& FO & & nahi ja sakta: Maliha Lodhi & rad-e-amal & uthane par Bharat aag bagola \\
\hline
\end{tabular}

Table 5(b). Interpretation of news headline

\begin{tabular}{ll}
\hline The Semantic Macro proposition & $\begin{array}{l}\text { These headlines have two-part headline which is pithy, the first head starts with a rhetorical use of the } \\
\text { phrase "bazar garam hai" an implicit reference to "awaz ko nh dabaya jasakta". These headlines } \\
\text { explicitly present the whole event by maximum possible words and encompassing the enormity of the } \\
\text { incident. }\end{array}$ \\
\hline $\begin{array}{l}\text { Participants Description and } \\
\text { Lexicalization }\end{array}$ & $\begin{array}{l}\text { "India, Pakistan, Akwamy Mutahida and Kashmiris" are main participants. Kashmir is a place which had } \\
\text { already many such horrific incidents in the past by India. There are actions by Pakistan and USA, India }\end{array}$ \\
\hline got furious. In Urdu very excellently portrayed India's picture as "aag bagola".
\end{tabular}

Table 6(a). News description of headline 5

\begin{tabular}{llllll}
\hline No. & Dawn Newspaper & The Nation Newspaper & Jang Newspaper & Express Newspaper & Khabrain Newspaper \\
5. & Hanoi protests Beijing's & China vows "decisive & South china sea par daway & Baheera Janoobi & Bharat ko Cheen ki \\
& $\begin{array}{l}\text { activities in South China } \\
\text { Sea }\end{array}$ & response" to sea & aur qabzay ki Jang mei aik & Cheen tanaza: Ishteal & janib say maza \\
& provocations & naya mod aa gaya. & $\begin{array}{l}\text { angezi par cheen ki } \\
\text { chakhaey jany ka imkan }\end{array}$ \\
\hline
\end{tabular}

Table 6(b). Interpretation of news headline

\begin{tabular}{ll}
\hline The Semantic Macro proposition & $\begin{array}{l}\text { These headlines put the whole news report in a nutshell, the background is not discussed but the message is } \\
\text { delivered, there is a conflict of China sea. Jang newspaper does not mention India's name as English } \\
\text { headlines too. But other two newspapers demonstrate power and gravity in bold manner to invoke readers' } \\
\text { interest in the news. }\end{array}$ \\
\hline $\begin{array}{l}\text { China and India are the main participants along with sea. Phrases are beautifully used to convey the threats. } \\
\text { India is basically threatened by China and the news is highlighted rhetorically in Pakistani Urdu } \\
\text { newspaper. Synecdoche "Hanoi and Beijing" has been used in headline of Dawn newspaper. }\end{array}$ \\
\hline The Global Super structure & These headlines give the details of the conflict between India and China on China Sea. \\
\hline
\end{tabular}

Table 7(a). News description of headline 6

\begin{tabular}{|c|c|c|c|c|c|}
\hline No. & Dawn Newspaper & $\begin{array}{l}\text { The Nation } \\
\text { Newspaper }\end{array}$ & Jang Newspaper & Express Newspaper & Khabrain Newspaper \\
\hline 14 & $\begin{array}{l}\text { Leaders of three } \\
\text { parties arrested in } \\
\text { Dr Asim case. }\end{array}$ & $\begin{array}{l}\text { Convicted leaders got } \\
\text { arrested. }\end{array}$ & $\begin{array}{l}\text { Waseem Akhtar Anees } \\
\text { Qaim Khani Qadir } \\
\text { Patel giraftar. }\end{array}$ & $\begin{array}{l}\text { Doctor Asim case motehda k } \\
\text { namzd meir Waseem } \\
\text { AkhtarAnees Qaim Khani Raouf } \\
\text { Sadiqui aur Qadir Patel } \\
\text { giraftar. }\end{array}$ & $\begin{array}{l}\text { MQM par crack down; } 3 \\
\text { griftaar. }\end{array}$ \\
\hline
\end{tabular}


Table 7(b). Interpretation of news headline

\begin{tabular}{ll}
\hline The Semantic Macro proposition & $\begin{array}{l}\text { The news headlines describe about the description of Dr Asim case. Leaders of three parties got } \\
\text { arrested. The statements depict clear and neutral meanings of news. ATC rejects bail pleas of al. } \\
\text { Two newspapers emphasize upon the word "conviction", however remaining don't mention the } \\
\text { term in their headlines. }\end{array}$ \\
\hline $\begin{array}{l}\text { Participants Description and } \\
\text { Lexicalization }\end{array}$ & $\begin{array}{l}\text { The news headline emphasizes about the arresting of the leaders of three parties. The word in the } \\
\text { news "leaders of three parties" depicts a clear and neutral order. The words "zamanaten manssokh", } \\
\text { "faraar" etc are the words which increase and emphasize the whole meanings of the statement. }\end{array}$ \\
\hline The Global Super structure & News hyper-texted the situation and portrayed differently in different newspapers. \\
\hline
\end{tabular}

Table 8(a). News description of headline 7

\begin{tabular}{llllll}
\hline No. & Dawn Newspaper & The Nation Newspaper & Jang Newspaper & Express Newspaper & Khabrain Newspaper \\
\hline 7. & Rallies held across & Pakistan to boost support & Kashmirion pr & Wafaqi kabina ka 19 july & Wafaqi kabina, Bharti \\
& $\begin{array}{l}\text { AJK to slam Indian } \\
\text { atrocities }\end{array}$ & to Kashmiris |Tuesday to & mazallim, mangal ko & ko yaum-e-sayyah & $\begin{array}{l}\text { mazalim k khilaf 19 july } \\
\text { ko yaum-e-sayyah } \\
\text { manane ka elaan }\end{array}$ \\
\hline
\end{tabular}

Table $8(b)$. Interpretation of news headline

\begin{tabular}{ll}
\hline $\begin{array}{l}\text { The Semantic Macro } \\
\text { proposition }\end{array}$ & $\begin{array}{l}\text { These headlines show the same cruelty of India on Kashmiri s. Pakistan is always with Kashmir, it also celebrates } \\
\text { black day. It shows solidarity with them. Dawn newspaper describes the event by using complete sentence. } \\
\text { Remaining four newspapers use phrase structure in headlines. }\end{array}$ \\
\hline $\begin{array}{l}\text { Participants Description and } \\
\text { Lexicalization }\end{array}$ & $\begin{array}{l}\text { Kashmir and Kashmiri people are main participants. The headlines focus on Kashmir issue. People are suffering. It } \\
\text { portrays a pitiable situation, circumstances are unbearable. Cruelty and brutality of India create great impact on } \\
\text { readers. They are celebrating black day. As black is the symbol of death, destruction. }\end{array}$ \\
\hline The Global Super structure & The global structure of these news reports summarizes the people response towards horrific incidents of Kashmir. \\
\hline
\end{tabular}

Table 9(a). News description of headline 8

\begin{tabular}{llllll}
\hline No. & Dawn Newspaper & The Nation Newspaper & Jang Newspaper & Express Newspaper & Khabrain Newspaper \\
\hline 8. & Celebration turns & 84 dead in "terrorist" & France mei phir & France phr sogwaar, truck & France: qaumi din par \\
& into carnage in & Nice truck rampage & dehshatgardi, truck hamlay & hamlay mei halaktain 84 ho & dehshatgardi, truck \\
& France & & mei halaktain 84 ho gaen, & gaen, bachay aur gairmulki & driver ne sainkdon \\
& & & 50 ki halat nazuk, mulk & shamil, aalmi rehnumao ki & afraad kuchal diye, 92 \\
& & bhar mei soag & muzzammat & halaak 125 zakhmi \\
\hline
\end{tabular}

Table 9(b). Interpretation of news headline

\begin{tabular}{ll}
\hline $\begin{array}{l}\text { The Semantic Macro } \\
\text { proposition }\end{array}$ & $\begin{array}{l}\text { Urdu news headlines have two parts. In the beginning of celebration of national day seems a good headline but } \\
\text { the end is sorrowful. It's the act of cruelty, innocent people died. The word carnage has been used by Dawn news, } \\
\text { but such righteous word was not used in its headlines when Indian atrocities were discussed. }\end{array}$ \\
\hline $\begin{array}{l}\text { Participants Description and } \\
\text { Lexicalization }\end{array}$ & $\begin{array}{l}\text { France and mass of France is main participant. The headline explicitly presents the whole event by using minimal } \\
\text { possible words and encompassing the enormity of the incident. Urdu newspapers use similar lexis when they } \\
\text { describe terrorism inside Pakistan, in Kashmir and outside Pakistan. However, English news headlines use } \\
\text { different synonyms to relate terrorism at different places. }\end{array}$ \\
\hline The Global Super structure & The global structure here differs significantly from its Urdu counterparts in terms of its length and topic selection. \\
\hline
\end{tabular}

Table 10(a). News description of headline 9

\begin{tabular}{llllll}
\hline No. & Dawn Newspaper & The Nation Newspaper & Jang Newspaper & Express Newspaper & Khabrain Newspaper \\
\hline 9. & People power helps & Mass arrests as Turkey & Turkey: Awaam ne & Turk awaam ne baghawat & Turk awam ne foji \\
& $\begin{array}{l}\text { Erdogan foil military } \\
\text { coup }\end{array}$ & coup crushed & baghawat kuchhal di & $\begin{array}{l}\text { kuchhal kr jamhooriat } \\
\text { bacha li }\end{array}$ & baghawat nakaam bna di, \\
& & & 265 halaak \\
\hline
\end{tabular}


Table 10(b). Interpretation of News Headline

\begin{tabular}{ll}
\hline $\begin{array}{l}\text { The Semantic Macro } \\
\text { proposition }\end{array}$ & $\begin{array}{l}\text { Turkish forces loyal to president Erdogan crushed an attempted military coup on Saturday after creeds } \\
\text { answered his call to take to the streets in support of the government and dozens of rebels abandoned their tanks. }\end{array}$ \\
\hline $\begin{array}{l}\text { Participants Description and } \\
\text { Lexicalization }\end{array}$ & $\begin{array}{l}\text { Main participants are Tayyib Erdogan and Turkish people and forces. Over 250 people were killed including } \\
\text { many civilians, after a faction of the armed forces tried to seize power using tanks and attack helicopters. } \\
\text { Different newspapers highlighted the event to compare it with democratic and dictatorship history of Pakistan. }\end{array}$ \\
\hline The Global Super structure & $\begin{array}{l}\text { These news headlines simply and effectively summarize the event. However, some newspapers used sarcastic } \\
\text { tone to broadcast this news; prime facie silently attacking on military actions of various coups in Pakistan. }\end{array}$ \\
\hline
\end{tabular}

Table 11(a): News description of headline 10

\begin{tabular}{|c|c|c|c|c|c|}
\hline No. & Dawn Newspaper & The Nation Newspaper & Jang Newspaper & Express Newspaper & Khabrain Newspaper \\
\hline 10. & $\begin{array}{l}\text { Turkish govt. rounds } \\
\text { up } 6,000 \text { after failed } \\
\text { coup }\end{array}$ & $\begin{array}{l}\text { Turkey widens } \\
\text { crackdown on military, } \\
\text { judiciary }\end{array}$ & $\begin{array}{l}\text { Turkey mei } \\
\text { operation clean up, } \\
\text { mazeed giraftarian }\end{array}$ & $\begin{array}{l}\text { Turkey awam ka jashan } \\
\text { fateh, baghawat ka } \\
\text { mansooba saaz general } \\
\text { amrici adday se giraftaar }\end{array}$ & $\begin{array}{l}\text { Turkey: baghawat } k \\
\text { sarghana foji afsar, jajjon } \\
\text { samait } 6 \text { hazar afraad } \\
\text { giraftaar }\end{array}$ \\
\hline
\end{tabular}

Table 11(b): Interpretation of news headline

\begin{tabular}{ll}
\hline The Semantic Macro proposition & $\begin{array}{l}\text { Erdgon accused the coup plotter of trying to kill him, and launched a purge of the armed forces, } \\
\text { which last used force to stage a successful coup. The annotation of victory and its subsequent } \\
\text { celebrations have been highlighted to great extent in Urdu newspapers as compared to English } \\
\text { News headlines which were precise and accurate rather than redundant and exaggerated. }\end{array}$ \\
\hline $\begin{array}{l}\text { Main participants are Turkish people. Many people are arrested, a war like situation, great hustle } \\
\text { and bustle everywhere. Turkey is passing throw critical period. }\end{array}$ \\
\hline The Global Super structure & The headlines simply but effectively summarize the event. \\
\hline
\end{tabular}

\subsection{Analysis of News Headlines at Social Practices Level}

At social practice level news have been analyzed in narrative way where the element of power, hegemony and ideology etc have been discussed while remaining in the frame of topical, lexical and contextual patterns. At this level of analysis headlines of 06 newspapers have been taken with equal number of English and Urdu newspapers.

Table 12. Comparison of headlines at social practices

\begin{tabular}{lllllll}
\hline \multicolumn{2}{l}{ English Newspapers } & & Urdu Newspapers & & \\
\hline & The Nation & Dawn & Express Tribune & Jang & Khabrain & Express \\
\hline 1 & Cyber crime, bill & Controversial & Cyber terrorists to & Cyber crime ka bill & Mutnaze cyber bill aik & Cyber crime par 14 \\
& passed in national & cybercrime bill & be jailed for 14 & paish, 5 caror tak & qanoon ban gaya & saal qaid, opposition ka \\
& assembly & becomes law & years & jurmana & & ehtajaj \\
\hline
\end{tabular}

"Cyber crime, bill passed in national assembly (The Nation)" Combining this "passed" provides some leeway that it is confirm and results in a framing that downplays the incident's potential magnitude. This could be partial representation, because of its focus on the event outcome rather than the back story (Shah, 2005 as cited in MacRitchie \& Seedat, 2008), the extended negotiation nor Mendoza's motives. This suggests an episodic framing which draws attention only to the event's resolution. The magnitude of the event is downplayed because of absent significant details. In the other newspaper this headline is written as; "Controversial cybercrime bill becomes law (Dawn)". Here the word "passed" is replaced by "becomes" showing that it is confirming that the bill has become the law. While in the third headline it is stated that; "Cyber terrorists to be jailed for 14 years (Express Tribune)". The topicalization afforded emphasizes significant role, while the chosen verb ironically portrays the situation. There was passive construction in the first headline while active construction in the second and passive in the third. While discussing the Urdu news headlines, "Cyber crime ka bill paish, 5 caror tak jurmana (Jang)", The social structure of this Urdu newspaper headline persuasively summarizes an incident with an attempt to mellow the importance of the incident. 
Table 13. Comparison of headlines at social practices

\begin{tabular}{|c|c|c|c|c|c|c|}
\hline & \multicolumn{3}{|c|}{ English Newspapers } & \multicolumn{3}{|l|}{ Urdu Newspapers } \\
\hline & The Nation & Dawn & Express Tribune & Jang & Khabrain & Express \\
\hline 2 & $\begin{array}{l}\text { Judge escapes } \\
\text { Quetta attack, } 74 \\
\text { dead }\end{array}$ & $\begin{array}{l}\text { Judge escapes } \\
\text { attack in } \\
\text { Quetta }\end{array}$ & $\begin{array}{l}\text { Hell fire in Quetta } \\
\text { Valley }\end{array}$ & $\begin{array}{l}\text { Quetta Main Phir } \\
\text { Dehshatgardi, Judge kay } \\
\text { kaflay par hamla bal bal } \\
\text { bach gaye }\end{array}$ & $\begin{array}{l}\text { Saneha quetta } \\
\text { wazeeer-e-alaa } k i \\
\text { nakami }\end{array}$ & $\begin{array}{l}\text { Quetta security high } \\
\text { alert, phir bomb } \\
\text { dhamaka judge ka squad } \\
\text { nishana bna }\end{array}$ \\
\hline
\end{tabular}

Placing the term in phrase-initial position capitalizes on the story's impact value. However, contradicts the term's semantic value, for it should represent no amendments. This lexical choice frames the event as something worse than it actually is and, thus, hints on sensationalism. The reference to "Quetta attack" likewise presents an inaccuracy that could have been deliberate to boost the event's prominence. The headline then succeeds in making ordinary readers, tourists or otherwise, relate to the situation. The topicalization accorded to the Quetta attack, that it takes syntactic precedence. While discussing the headline in Urdu then the same trend has been seen, that the word Quetta attack is emphasized. In all these three headlines active construction is present. The emphasis is on the subject i.e. Quetta attack and therefore the subjectivity is also present. The global superstructure of this Urdu newspaper headline persuasively summarizes a tragic incident with an attempt to mellow the severity of the incident at one hand, and showing a somewhat softer and helpless image of the government agencies, on the other hand. It contains almost all the details of causalities with figures.

Table 14. Comparison of headlines at social practices

\begin{tabular}{lllllll}
\hline \multicolumn{2}{l}{ English Newspapers } & & Urdu Newspapers & \\
\hline & The Nation & Dawn & Express Tribune & Jang & Khabrain & Express \\
\hline 3 & Talibans set & Helicopter & Punjab govt. & Punjab hakumat ke & Taliban ne Punjab & Pakistani helicopter ki \\
& Punjab Govt. & crashed in & helicopter crashes & helicopter ki & hakumat kay helicopter & $\begin{array}{l}\text { Afghanistan main hangami } \\
\text { helicopter on fire }\end{array}$ \\
& Afghanistan & in afghanistan & Afghanistan main & ko aag laga di, amla & $\begin{array}{l}\text { landing, Taliban ne jala dia, } \\
\text { amla yarghamal }\end{array}$ \\
\hline
\end{tabular}

In the headline "Talibans set Punjab Govt. helicopter on fire (The Nation)" the active construct is used to tell about the situation along with the active construct to create attraction and interest of the reader. While in the headline, "Helicopter crashed in Afghanistan (Dawn)" active construct is used and same is found in Urdu headline "Punjab hakumat ke helicopter ki Afghanistan main hangami landing (Jang)" these headlines are headlines with pointers. "Punjab govt. helicopter crashes in Afghanistan (Express Tribune)". This headline puts the whole news report in a nutshell, as reported by "Daily Khabrain", "Taliban ne Punjab hakumat kay helicopter ko aag laga di, amla yarghamal". At the surface level it shows that incidents of terrorism with a considerable number of people being kidnapped and injured. This headline appears to be the obvious summary of the news event written in the standard "whowhat- where-when" formula of news headline style (Bell and Garret, 1998: 75). Close analysis shows that the headline does not only mention the terrorism incident. Very artfully the word "incidents" is used to show the magnanimity of the event, without stating the obvious.

Table 15. Comparison of headlines at social practices

\begin{tabular}{llllll}
\hline & English Newspapers & & Urdu Newspapers & \\
\hline & The Nation & Dawn & Express Tribune & Jang & Khabrain \\
\hline \multirow{2}{*}{ Indian terrorism in } & India is doing & Indian excesses in & Kasmiriyon par & Kashmir main bharti & Maqbooza Kashmir \\
& Kashmir will not be & unjust with & Kashmir terrorism & dehshatgardi hai & deshatdgardi \\
& kashmiris & & bardasht nahin kijaegi & main shehriyon par & bharatiziyadati \\
\hline
\end{tabular}

Table 15 represents the head words in news headlines "terrorism". Only one newspaper (Express) does not use the word terrorism for Indian forces on poor Kashmiris. However, other 05 newspapers use the word terrorism for expressing their concerns on the brutal attacks of India in Kashmir. The ideology is being represented in the word "bardasht nahin hogi" which means terrorism would not be tolerated at any cost. Words "unjust" and "excessive" points out the aggravated situation of the cruelty of the unending sequences of the event. The intent of editors is clear that they want to evoke readers attention and compassion regarding the event. This lexical choice frames the event as something worse than it actually is and, thus, hints on sensationalism. The reference 
to "Indian Terrorism" likewise presents an inaccuracy that could have been deliberate to boost the event's prominence. The headline then succeeds in making ordinary readers, tourists or otherwise, relate to the situation.

Table 16. Comparison of headlines at social practices

\begin{tabular}{|c|c|c|c|c|c|c|}
\hline & \multicolumn{3}{|c|}{ English Newspapers } & \multicolumn{3}{|l|}{ Urdu Newspapers } \\
\hline & The Nation & Dawn & Express Tribune & Jang & Khabrain & Express \\
\hline 5 & $\begin{array}{l}\text { Two suicide } \\
\text { bombers kill } 13 \\
\text { persons near } \\
\text { Mogadishu airport }\end{array}$ & $\begin{array}{l}\text { Twin suicide } \\
\text { bombs kill } 13 \\
\text { near Mogadishu } \\
\text { airport }\end{array}$ & $\begin{array}{l}13 \text { dead in a suicide } \\
\text { bomb attack close to } \\
\text { Mogadishu airport }\end{array}$ & $\begin{array}{l}\text { Mogadishu airport } \\
\text { qareeb khudkush } \\
\text { hamla awaron ne } 13 \\
\text { afrad ko halak krdia }\end{array}$ & $\begin{array}{l}13 \text { afrad Mogadishu } \\
\text { airport k qareeb } \\
\text { khudkush hamla } \\
\text { awaron ka nishana } \\
\text { bany }\end{array}$ & $\begin{array}{l}\text { Khudkush hamla } \\
\text { awaron ne } 13 \text { afrad ko } \\
\text { Mogadishu airport } k \\
\text { qareeb dehshat gardi } \\
\text { ka nishana bnaya }\end{array}$ \\
\hline
\end{tabular}

This headline from "Express Urdu" is long, with multiple heads consisting of four sections. Each section highlights an aspect of the incident and the details of the report. The main participants of the headline are the victims and the general public. The first section introduces the event: "Khudkush hamla awaron ne 13 afrad ko Mogadishu airport $k$ qareeb dehshat gardi ka nishana bnaya" (Express Urdu). "Two suicide bombers kill 13 persons near Mogadishu airport" (The Nation) mention the death toll and the injured people which are dramatically high in contrast to the other routine bomb blast incidents taking place. These headlines are a powerful ideological statement of the newspaper. The readers are emotionally and mentally triggered with the diction used in them. On the other hand, the language signifies the national failure of the government as well.

Table 17. Comparison of headlines at social practices

\begin{tabular}{|c|c|c|c|c|c|c|}
\hline & \multicolumn{3}{|c|}{ English Newspapers } & \multicolumn{3}{|l|}{ Urdu Newspapers } \\
\hline & The Nation & Dawn & Express Tribune & Jang & Khabrain & Express \\
\hline 6 & $\begin{array}{l}\text { Ex employee } \\
\text { kills } 19 \text { with } \\
\text { knife attack at a } \\
\text { care home }\end{array}$ & $\begin{array}{l}\text { Ex-employee kills } \\
19 \text { in Japan care } \\
\text { home knife attack }\end{array}$ & $\begin{array}{l}19 \text { killed by an } \\
\text { ex-employee in } \\
\text { japan care home } \\
\text { knife attack }\end{array}$ & $\begin{array}{l}\text { Sabiq mulazim nejapan } \\
\text { mein hifazati ghar main } \\
\text { firing kar ky } 19 \text { afrad ko } \\
\text { chaku se mar dala }\end{array}$ & $\begin{array}{l}\text { Japan k ek Care home } k \\
\text { sabiq mulazim ne } 19 \\
\text { afrad chaku k hamlay se } \\
\text { mar dive }\end{array}$ & $\begin{array}{l}\text { Japan men sabiq } \\
\text { mulazim ne } 19 \\
\text { afrad ko mar dala }\end{array}$ \\
\hline
\end{tabular}

"Ex employee kills 19 with knife attack at a care home" (The Nation) The main participants in this headline are the Ex employee and the victims at the same place of attack and the place is mentioned explicitly. "Sabiq mulazim nejapan mein hifazati ghar main firing kar ky 19 afrad ko chaku se mar dala" This headline from "Daily Jang" is the perfect example of this statement. Casual examination shows that 19 persons were attacked and that the death toll has been mentioned. This headline is a straight forward summary of news even written in the format of "who-what-where-when". "19 killed by an ex-employee in Japan care home knife attack" (Express Tribune). The persons who were coming out of care home services were attacked by ex-employee. This headline can also be viewed as an editorial comment and evaluation. It shows an underlined image of more turbulent affairs than a mere attack. The headline places the victims as the "sole actors" of the event.

Table 18. Comparison of headlines at social practices

\begin{tabular}{|c|c|c|c|c|c|c|}
\hline & \multicolumn{3}{|l|}{ English Newspapers } & \multicolumn{3}{|l|}{ Urdu Newspapers } \\
\hline & The Nation & Dawn & Express Tribune & Jang & Khabrain & Express \\
\hline 7 & $\begin{array}{l}\text { Attack on church in } \\
\text { France claimed by IS }\end{array}$ & $\begin{array}{l}\text { IS claims attack } \\
\text { on French church }\end{array}$ & $\begin{array}{l}\text { French church } \\
\text { attacked by IS }\end{array}$ & $\begin{array}{l}\text { Fransisi girja } \\
\text { ghar mein hamla }\end{array}$ & $\begin{array}{l}\text { Fransisi girja ghar par hamla, } \\
\text { IS ne zimadari qubul krli }\end{array}$ & $\begin{array}{l}\text { Fransisi Girja } \\
\text { Ghar par Hamla }\end{array}$ \\
\hline
\end{tabular}

This headline from "Khabrain" is long, with multiple heads consisting of two sections. Each section highlights an aspect of the incident and the details of the report. The main participants of the headline are the victims and the general public. The first section introduces the event: "Fransisi girja ghar par hamla". The mere mentioning of the word "girja ghar" has very high implications but here the state has failed miserable. Second section mention "IS ne zimadari qubul krli" whereas the death toll and the injured people were not mentioned here. The main participants in this headline are the victims and the protestors at the same place of attack and the places are mentioned explicitly. "IS claims attack on French church" (Dawn). It methodically applies religious and national lexicalization. The language used in almost all headlines deviate towards religious issue more intensively as 
compared to the national issue. The rhetoric used in Urdu newspapers make the news more religious than national. The "France" has been used as adjective of the "Church" in all three Urdu headlines. However, 02 English newspapers relate the news as national as well as religious where France has been made dominated by making it the object of the sentence. On the whole, both national and religious ideological perspective has been highlighted in the news headlines.

Table 19. Comparison of headlines at social practices

\begin{tabular}{|c|c|c|c|c|c|c|}
\hline & \multicolumn{3}{|c|}{ English Newspapers } & \multicolumn{3}{|l|}{ Urdu Newspapers } \\
\hline & The Nation & Dawn & Express Tribune & Jang & Khabrain & Express \\
\hline 8 & $\begin{array}{l}\text { Two Pak Army } \\
\text { jawans martyred } \\
\text { in Karachi }\end{array}$ & $\begin{array}{l}\text { Attack in Karachi: } \\
\text { two jawans } \\
\text { martyred }\end{array}$ & $\begin{array}{l}2 \text { armymen shot } \\
\text { dead in Karachi }\end{array}$ & $\begin{array}{l}\text { Karachi mein pak army } k \\
\text { do jawan gari p hamlay } \\
k \text { dooran shaheed }\end{array}$ & $\begin{array}{l}\text { Shehr-e-quaid main pak } \\
\text { fauj ki gari par hamla } 2 \\
\text { jawan shaheed }\end{array}$ & $\begin{array}{l}\text { Do fauji jawan } \\
\text { Karachi mein dehshat } \\
\text { gardi ka shikar }\end{array}$ \\
\hline
\end{tabular}

"Two Pak Army jawans martyred in Karachi (The Nation)" This lexical choice frames the event as something worse than it actually is and, thus, hints on sensationalism. The reference to "martyred" likewise presents an inaccuracy that could have been deliberate to boost the event's prominence. The headline then succeeds in making ordinary readers, tourists or otherwise, relate to the situation. The emphasis is on the subject i.e. martyred and therefore the subjectivity is also present. "Attack in Karachi: two jawans martyred (Dawn)". This is pointed headline that points the readers toward the attack in Karachi. Whereas the headline of express tribune states; " 2 armymen shot dead in Karachi" it is a short narrative headline which explains the situation very well. While discussing the news headlines of Urdu newspapers, "Karachi mein pak army k do jawan gari p hamlay k dooran shaheed" (Jang), narrative style is adopted. On the other hand "Shehr-e-quaid main pak fauj ki gari par hamla 2 jawan shaheed" (Daily Khabrain), a twist is there because Karachi is replaced by Shehr-e-Quaid.

Table 20. Comparison of headlines at social practices

\begin{tabular}{|c|c|c|c|c|c|c|}
\hline & \multicolumn{2}{|l|}{ English Newspapers } & & \multicolumn{3}{|l|}{ Urdu Newspapers } \\
\hline & The Nation & Dawn & Express Tribune & Jang & Khabrain & Express \\
\hline 9 & $\begin{array}{l}\text { Jeddah Suicide } \\
\text { Bomber identified as a } \\
\text { Pakistani: Saudi } \\
\text { interior ministry }\end{array}$ & $\begin{array}{l}\text { Jeddah suicide } \\
\text { bomber was } \\
\text { Pakistani: Saudi } \\
\text { interior ministry }\end{array}$ & $\begin{array}{l}\text { Jeddah suicidal } \\
\text { bomber was a } \\
\text { Pakistani: says Saudi } \\
\text { interior ministry }\end{array}$ & $\begin{array}{l}\text { Jeddah khudkush } \\
\text { dhamakay mein ek } \\
\text { pakistani mulawis }\end{array}$ & $\begin{array}{l}\text { Jeddah khudkush } \\
\text { dhamaka krnay wala } \\
\text { ek Pakistani tha }\end{array}$ & $\begin{array}{l}\text { Jeddah mein } \\
\text { khudkush dhamaka }\end{array}$ \\
\hline
\end{tabular}

"Jeddah Suicide Bomber identified as a Pakistani: Saudi interior ministry" Combining this with "identified" provides some leeway for the confirmation that the identification has been made and results in a framing that downplays the incident's potential magnitude. "Jeddah suicide bomber was Pakistani: Saudi interior ministry" (Dawn) This could be partial representation, because of its focus on the event outcome rather than the back story (MacRitchie \& Seedat, 2008), the extended negotiation nor Mendoza's motives. This suggests an episodic framing which draws attention only to the event's resolution. In the news headline of Khabrin it is stated that "Jeddah khudkush dhamaka krnay wala ek Pakistani tha" the magnitude of the event is downplayed because of absent significant details.

Table 21. Comparison of headlines at social practices

\begin{tabular}{|c|c|c|c|c|c|c|}
\hline & \multicolumn{3}{|c|}{ English Newspapers } & \multicolumn{3}{|l|}{ Urdu Newspapers } \\
\hline & The Nation & Dawn & Express Tribune & Jang & Khabrain & Express \\
\hline 10 & $\begin{array}{l}\text { During protests } \\
\text { against police in } \\
\text { Dallas five } \\
\text { officers killed in a } \\
\text { sniper attack }\end{array}$ & $\begin{array}{l}\text { Dallas sniper } \\
\text { attack: } 5 \text { officers } \\
\text { killed during } \\
\text { protests against } \\
\text { police }\end{array}$ & $\begin{array}{l}5 \text { officers killed in } \\
\text { a sniper attack in } \\
\text { Dallas in the } \\
\text { protests against } \\
\text { police }\end{array}$ & $\begin{array}{l}\text { Dallas mein Police } \\
\text { ky khilaf ehtjaj } k \\
\text { doran ek gunman ne } \\
5 \text { police officer } \\
\text { halak kr dye }\end{array}$ & $\begin{array}{l}5 \text { police afsaron ko } \\
\text { ek shakhs ne police } \\
\text { k khilaf ehtejaji } \\
\text { julus } k \text { dorran } \\
\text { Dallas mein mar dia }\end{array}$ & $\begin{array}{l}\text { America k shehr Dallas } \\
\text { mein ek shidat pasand ne } \\
\text { police kay khilaf ehtijaji } \\
\text { julus mein } 5 \text { afsaaro ko } \\
\text { halak kr dala }\end{array}$ \\
\hline
\end{tabular}

"During protests against police in Dallas five officers killed in a sniper attack" (The Nation). Placing the term in phrase-initial position capitalizes on the story's impact value. However, contradicts the term's semantic value, for it should represent no amendments. "Dallas sniper attack: 5 officers killed during protests against police" 
(Dawn) The headline then succeeds in making ordinary readers, tourists or otherwise, relate to the situation. The topicalization accorded to the pointed headlines, Dallas Snipper attack, that it takes syntactic precedence. While discussing the headline in Urdu Newspaper Express then the same trend has been seen, "America $k$ shehr Dallas mein ek shidat pasand ne police kay khilaf ehtijaji julus mein 5 afsaaro ko halak kr dala" that the word "attack" is emphasized. In all these three headlines active construction is present. The emphasis is on the subject i.e. sniper attack in Dallas and therefore the subjectivity is also present.

\section{Findings and Discussions}

The headline structure and cohesive devices show that language is a social practice in itself not only represents and signifies other social practice but it also constitutes other features such as the exercise of power, domination, prejudice, resistance and so forth. The news headlines have been discussed at different levels. The language used in the headlines has been used in different contexts based upon the nature of the news discussed and quality of the event for its importance sake and clarity purposes. Data finds out that text used in news headlines is most of the time context dependent in its nature and superficiality. As far as speech and narration is concerned, news headlines use direct and indirect speech both. At times these are free direct speech and free indirect speech. When used as having both of the speech parts i.e. reporting clause and reported clause, the arrangement of the clause is inverted in the manner that reported clauses precede the reported clauses.

News headlines use different viewpoints including first person, second person and third person omniscient. But data shows that more that at $90 \%$ of the time and places, news headlines use third person omniscient point of view, which is termed as strong and vivid style of using language. Data also reflect that English news paper used ultimately different style of expressions as compared to Urdu news and headlines. Similarly, the syntactic structure used in news headlines is far more varied and extended into different negotiable categories. The subject verb agreement and subject verb inversion type of phenomenon is quite frequent in the textual structure of the news headlines.

At discursive, textual and social practice levels, the purpose of the news can be defined and interpreted differently. Quite often, the purpose of the news is to convey information but many times it is to exaggerate and turn information into humor fun or threat. Readers' implied gestures and emotions are invoked and evoked in the language used in news. Tone used in the news headlines is convincing, authoritative and sometimes alarming or even threatening. The language of Urdu news is more pervasive and lexically dense due to its local contextual features, however tome of English news headlines is serious and empirical in confirmation and authentication. The word choice used in Urdu and English headlines is also attention grabbing and interest provoking. Adjectives, modifiers and specifiers are used in abundance in both types of Urdu and English news headlines. The figurative markers like similes, metaphors, hyperbole, pun, understatement, paradoxical utterances, metonymy and synecdoche have been used very frequently in the structure of Urdu and English newspapers.

The study summarizes with the findings that different newspapers use different level of headings for certain purposes. These objectives can be apparently matched with their own national or financial agenda but most of the time this purpose is even not clear for these media houses or producers. The headlines show difference of opinion at all the three levels of Fairclough's model i.e. textual level, discursive level and at the level of social practices. According to analysis and interpretation it is also found that cultural background and information has strong influence on the style and words which are selected for the news and it is also clear that people living in specific area have different interest according to the news and news words are used accordingly. Different techniques are used to highlight the information and these techniques also show density of news.

Regarding news headlines, these three newspapers are writing differently in case of grammar and using ornaments for the clarification of news and area where news is being printed matters a lot that in which way people want to have news in front of them. Dawn news is not using the exaggeration and figure of speech, news is always in simple statement, figurative language is avoided. Jung news is also showing framework in favor of government, where realism is used against opposition. Exaggeration is being developed in the statements. Express news is using abstract words to clarify the idea regarding thoughts of people and is carefully used for the audience who are keenly observing the news and showing interest in reading newspapers.

\subsection{Interpretation of Research Questions Based Upon the Findings of the Study}

\subsubsection{What Is the Significance of Headlines in Perspective of Discourse and Society?}

Data indicates that language plays vital and pivotal role in making, breaking and reshaping public opinion most specifically in media discourse. Media discourse represented in newspaper draw people attention to great extent as common masses indulge deep interest in what is happening in their surroundings. Findings obtained from 
analysis and interpretation of data reflects the significance and gravity of news headlines and their role in linguistic discourse in general and social practices and societal concerns in particular. Language used in media has great variance on textual and morphological structures. These variations are done consciously as well to attract readers' attention towards particular political, social or intellectual phenomenon.

\subsubsection{What Is the Role of Headlines in Representation of Same Event in Different Ways?}

Different newspapers highlight different events with different perspectives. Knowingly or unknowingly, different newspapers represent same event or happening in different way. Any important incident or unforeseen accident draws people attention and form public opinion and later un/truthful law in their minds. Findings show that same news was neither given same weight nor given same polarity or sensitivity by different newspapers. A "6" column most important news of one newspaper was represented as a nominal news of "2" column by different newspaper. Furthermore, the narrative and linguistic style of the same news was also changed in different newspapers.

\subsubsection{What Is the Impact of Headlines in Construction and Propagation of Ideologies?}

This study highlights different textual, morphological, lexical and inter-sentential elements of news headlines published in Urdu and English newspapers. It was found that English headlines most of the time portray any incident or event in concrete way without getting sarcastic or humoristic. However, Urdu news headlines on the other hand use a lot of lexical and pragmatic features to construct different mindset and ideology of the readers. It was also observed that propaganda type mindset and news were published by Urdu newspapers more frequently than English newspapers. The ultimate reason could be the proposed readers that these newspapers have. Obviously, English newspapers are mostly used and read by educated people who normally don't believe on concocted stories or flowery utterances, so such elements are not found in the language of English newspapers. On the other hand, readers of Urdu newspapers belong to all age classes of different professions and different intellect forums, so producers (media houses) consider it easy to shape or reshape the ideology towards certain phenomenon or perspectives. So they use a large number of linguistic and pragmatic strategies to attract readers' attention and form their opinion to construct certain ideology.

\subsubsection{To What Extent Are There Linguistic Differences in Headlines of Various Newspapers?}

Findings obtained from the current study show a significant difference in using different linguistic features in news headlines. These headlines are different in occupying different syntactic and grammatical structures. The most frequent difference found in news headlines is the use of different adjectives, modifiers and specifiers in different news. These linguistic differences are used to increase or decrease the intensity of any occurrence or event taken place in the world. The language used in headlines is different in terms of context, style, rhetorical devices, point of views, lexical structure, purpose, atmosphere, mood and tone etc. The language used in headlines has been found very much different from formal, informal or standard language. Most of time the linguistic derivations used in news headlines is ranked as colloquial in utterance and rhetorical in structure.

\subsubsection{How Linguistic Features of Headlines Effect the Social Features of Discourse Within the Society?}

Language used or perceived effects human thoughts and mind which subsequently play significant role in the society. The discourse and society are very important in representing power or showing hegemony or constructing different ideologies. The findings obtained from data analysis and interpretation strengthens the assumption that language of news effect social features of linguistic discourse and societal norms. The news headlines shape and reshape the common and general beliefs of readers. It is not hard to find out the common social or political agenda of any newspaper by looking at few daily newspapers of that media house. It is not the importance of any event people are looking for, but it's the importance of newspaper that makes any event more important or less important. Data clearly explores the different linguistic features and linguistic deviations that have been used on deliberate purpose to construct or mould certain ideology in the society at national and international forum.

\section{Conclusion and Recommendations}

The current study highlighted the linguistic and contextual features of media discourse with special emphasis on the language used in newspapers headlines. Newspapers report the same event in different ways by manipulating headlines. The headlines used in newspapers increase or decrease news worthiness of any incident or event. The current study has explored those differences by using different aspects of Critical Discourse Analysis. It concentrates on the issue how different newspapers use headlines deliberately to manipulate the events. Different media houses portray similar type of events in different ways. The apparent reason for using different linguistic and contextual techniques is to create entertainment, sympathy, embarrassment or amusement in the minds of the 
readers. Moreover, Urdu and English newspapers use a variety of but different linguistic and rhetorical techniques in order to draw the readers' attention. The current study has explored the news worthiness and their importance through discussing different linguistic, discursive and social practices.

The further recommendations based upon the results of this study are given as under:

1) The study can be replicated to analyze different textual and contextual features of electronic news.

2) It is suggested that readers should get awareness about different linguistic features and their reason of using such textual devices in different newspapers. Only then, they can understand and interpret news well.

3) The study recommends that there should be compulsory trainings of media personnel on using pertinent language and rhetoric in media discourse. It will not only enhance their professional worth, but save public from getting dejected and threatened on the hyper active language used by them in newspapers.

4) The study further recommends enforcing code of conduct for media houses to use such language and rhetoric in media discourse which is in regulation with mutual interest and national integrity. The language used in news makes or break public opinion, so it should be used with great care and responsibility.

\section{References}

Bell, A. (1991). Language of News Media. Oxford: Blackwell.

Develotte, C., \& Rechniewski, E. (2001). Discourse analysis of newspaper headlines: A methodological framework for research into national representations. Web Journal of French Media Studies, 4(1).

Fairclough, N (1989). Language and power. London: Longman

Fairclough, N (1995). Critical Discourse Analysis: The Critical Study of Language. London: Longman

Fairclough, N. (1992). Discourse and social change. Cambridge: Polity Press

Fairclough, N., \& Wodak, R. (1997). Critical Discourse analysis. In T. A Vandijk (Ed.), Discourse as social Interaction. London: Saga.

Ghannam, N. (2011). Newspaper ideology: A critical discourse analysis of an event published in six Lebanese newspapers (M.A dissertation). University of the Witwatersrand, South Africa.

Keller, L., Aperiat, T., \& Georgson, M. (2008). Strategic brand management: A European perspective. Harlow: Pearson Educational limited

Khodabandeh, F. Z. (2007). A Contrastive Analysis of English and Persian News Headlines. The Linguistic Journal, 2(1), 91-127.

Lagerwerf, L. (2002). Deliberate ambiguity in slogans Document. Designee, 3, 245-260.

MacRitchie, V., \& Seedat, M. (2008). Headlines and Discourses in Newspaper Reports on Traffic Accidents. South African Journal of Psychology, 38(2). https://doi.org/10.1177/008124630803800206

Mardh, I., (1980). Headlines: On the Grammar of English Front Page Headlines. Malmo.

McQuail, D. (1994). Mass communication and the public interest: Towards social theory for media structure and performance. In D. Crowley \& D. Mitchell (Eds.), Communication theory today (pp. 235-253). Cambridge: Polity.

Nawaz, R., Thompson, P., McNaught, J., \& Ananiadou, S. (2010). Meta-Knowledge Annotation of Bio-Events. In Proceedings of LREC 2010, pp. 2498-2507.

Praskova, E. (2009). Grammar in Newspaper Headlines. Bachelor Paper. University of Pardubice.

Reah, D. (1998). The language of newspapers. London: Routledge.

Richardson, J. (2007). Analysing Newspapers: An Approach from Critical Discourse Analysis. London: Palgrave Macmillan. https://doi.org/10.1007/978-0-230-20968-8

Shiffirin, D. (1994). The handbook of Discourse Analysis. University of Chicago Press.

Taiwo, R. (2007). Language, ideology and power relations in Nigerian newspaper headlines. Nebula, 4(1), 218-245.

Ungerer, F. (Ed.). (2000). English media texts past and present language and textual structure. Philadelphia, PA: John Benjamins. https://doi.org/10.1075/pbns. 80

Van Dijk, T. A. (1995). Discourse as Structure and Process. London: Sage. 
Van Dijk, T. A. (1998). Critical Discourse analysis. “Welcome to E-Commerce Times". Ecommerce times.

Wodak, R., \& Meyer, M. (2009). Critical discourse analysis: History, agenda, theory, and methodology. In R. Wodak \& M. Meyer (Eds.), Methods of critical discourse analysis (pp.1-32). Amsterdam: Sage Publications Ltd.

\section{Copyrights}

Copyright for this article is retained by the author, with first publication rights granted to the journal.

This is an open-access article distributed under the terms and conditions of the Creative Commons Attribution license (http://creativecommons.org/licenses/by/4.0/). 